\title{
Prediction of drainage water chemistry by experimental data (on the example of the Nakhodka porphyry copper prospect, Western Chukotka, Russia)
}

\author{
Daria Yablonskaya ${ }^{1, *}$, Tatiana Lubkova $^{1}$, Tatiana Shestakova ${ }^{1}$, and Natalia Strilchuk ${ }^{1}$ \\ ${ }^{1}$ Faculty of Geology, Moscow State University, 119234 Moscow, Russia
}

\begin{abstract}
Prediction of drainage water chemistry is a critical part of mine planning; particularly water and mine waste management. This study investigates a potential composition of drainage water for various storage times of sulphide-bearing geological materials by experimental data. The paper presents the results of Short-Term Leach tests and Humidity Cell tests for geological materials of the Nakhodka porphyry copper ore field, the Baimka ore trend (Western Chukotka, Russia). The results obtained can be used to forecast of wastewater composition as well at the initial stage of storage of sulphide-bearing geological materials as over the long-term.
\end{abstract}

\section{Introduction}

Sulphide minerals in ore deposits are formed under reducing conditions in the absence of oxygen. When exposed to atmospheric oxygen or oxygen-saturated water as a result of mining, mineral processing, earthworks, or other processes related to earth-moving, sulphide minerals can become unstable and oxidize. The oxidation of iron-containing sulphide minerals leads to the formation of highly mineralized sulphate water with low acidity and high concentrations of ore and trace elements [1].

Similar processes occur during the storage of sulphide-bearing geological materials in dumps. Oxygen-saturated atmospheric precipitation falling into the dump will penetrate into or flow down over the dump's surface. As a result, oxidation processes will be stimulated and acidic high-metal drainage will be formed [2]. The effluent of such drainage water into natural watercourses causes changes in their chemical composition, adversely affects water quality and as a result leads to degradation of the environment.

Thus, prediction of drainage water quality is an essential part of environmental impact assessment of field development. It's based on the results of static geochemical tests to estimation of rock acid generation and neutralization potential and on data of laboratory study of weathering by experimental modelling of "water-rock" interaction under static and dynamic conditions. It's thus possible to predict a change in drainage water composition at various stages of weathering [2].

*Corresponding author: daria.yablonskaya@gmail.com 


\section{Brief geological review and surface water chemistry}

The Baimka trend is a part of the Oloi metallogenic zone, where $\mathrm{Cu}-\mathrm{Mo}-\mathrm{Au}$ porphyry systems were formed in a continental arc environment. Porphyry deposits are related to the Early Cretaceous Egdykgich Complex, whose monzonitic bodies intrude into the Upper Jurassic volcanic and volcanic-sedimentary sequence. Four types of altered rocks were identified within the Baimka ore trend: biotite-potassium feldspar-quartz, propylite, quartz-sericite and argillite.. Porphyry $\mathrm{Cu}-\mathrm{Mo}$ ore mineralization is spatially associated with potassic feldspar and quartz - sericite zones, including stockworks of quartz carbonate veins and veinlets with bornite, chalcopyrite, molybdenite, and pyrite. In some areas a zone of secondary sulphide enrichment with bornite and chalcocite are developed. Minor minerals are hematite, sphalerite, galena. One highly profitable areas for development in the Baimka trend is the Nakhodka porphyry copper ore field [3].

The copper porphyry mineralization determine surface water compositions. Applied to the Nakhodka ore field, natural water draining sulphide mineralization is characterized by acidic $(\mathrm{pH}=3.5-4.5)$ sulphate magnesium or calcium-magnesium composition, and medium - high salinity (0.5-2.2 g/l, maximum - $25 \mathrm{~g} / \mathrm{l})$. According to the ratio of metal concentration and $\mathrm{pH}$ value such water must be classified as high-metal acid water. Background watercourses are neutral $(\mathrm{pH}=6.4-7.3)$, calcium sulphate-hydrocarbonate with low salinity $(0.06-0.12 \mathrm{~g} / \mathrm{l})[4,5]$.

The acid generation potential of geological materials of the Baimka ore zone significantly exceeds their ability to neutralize the resulting acid; hence, there is a high probability of acid mine drainage from waste dumps during the field development [6].

\section{Materials and methods}

Prediction of the drainage water composition is based on the results of geochemical static short-term leach tests and kinetic humidity cell tests for samples of representative rock types. A total of 18 samples of underground host rocks and low-grade ores from drill holes were collected for geochemical investigations.

Static short-term leach tests simulate the activation of sulphide oxidation in geological materials as a result of their interaction with atmospheric precipitation. The composition of filtrates corresponds to the potential drainage water's composition at the initial stage of geological materials storage [2]. Static tests were conducted for all samples of rocks and low-grade ores.

Kinetic humidity cell tests simulate rock weathering (in laboratory conditions). Results of these tests must be considered to forecast of drainage water composition in case of longterm storage of geological materials. The testing algorithm is determined at [2]; it includes the weekly sample interaction with deionized water, collection and analysis of weekly filtrates. Temperature and humidity are controlled throughout the experiment. Kinetic tests were conducted for 3 samples; these samples were choosen by according to results of determine of acid generation potential (given in [6]).

All leachates were tested for chemical composition and analysed for trace element concentration in laboratories of the Department of Geochemistry, Geological Faculty, Lomonosov Moscow State University. Leachate $\mathrm{pH}$ was measured by potentiometry with a pH-meter Expert-001 and a pH-meter Hanna Instrument (tester Checker-1) which were calibrated against commercial buffer solutions $(\mathrm{pH} \mathrm{4,} \mathrm{pH} 7, \mathrm{pH} \mathrm{10)}$ before each batch of measurements. Conductivity (specific conductance) was measured using a portable conductivity meter HM Digital COM80. Concentrations of major ions were determined by methods of volume titration (bicarbonate, chloride, sulfate, calcium and magnesium) and atomic absorption spectrometry (sodium, potassium; spectrometer ContrAA 700 by 
Analitik Jena). Trace element concentrations were analyzed by ICP-MS (mass-spectrometer Element 2 by Thermo Finnigan). Leachates were pre-filtered used $0.45 \mu \mathrm{m} \mathrm{MCE}$ membrane (Merck Millipore), then filtrates were acidified with $\mathrm{HNO}_{3}(1: 1)$ to $\mathrm{pH}<2$.

\section{Results and discussion}

Results obtained indicate that at the initial stage of storage of sulphide-bearing geological materials drainage water composition is similar to one of surface water in total but can be differ by higher levels of $\mathrm{pH}$ and, for some types of rocks, elevated concentrations of trace metals (Table 1, Fig. 1A).

Table 1. Chemical composition of surface water and leachates for geological sulphide-bearing materials (except high-pyritized rocks).

\begin{tabular}{|c|c|c|c|c|c|c|c|c|c|c|c|c|c|c|}
\hline \multirow{3}{*}{ 坖 } & \multicolumn{4}{|c|}{ Surface water $[4,5]$} & \multicolumn{4}{|c|}{ Initial stage } & \multicolumn{6}{|c|}{ Long-term } \\
\hline & \multicolumn{2}{|c|}{$\begin{array}{l}\text { Back- } \\
\text { ground }\end{array}$} & \multicolumn{2}{|c|}{$\begin{array}{c}\text { Ore } \\
\text { zone }\end{array}$} & \multicolumn{2}{|c|}{ Static test } & \multicolumn{2}{|c|}{ Week 1 - 5} & \multicolumn{2}{|c|}{ Week 10} & \multicolumn{2}{|c|}{ Week 30} & \multicolumn{2}{|c|}{ Week 55} \\
\hline & $\min$ & $\max$ & $\min$ & $\max$ & $\min$ & $\max$ & $\min$ & $\max$ & $\min$ & $\max$ & $\min$ & $\max$ & min & $\max$ \\
\hline pH & 6.4 & 6.7 & 3.2 & 5.2 & 7.0 & 7.7 & 7.1 & 8.1 & 7.0 & 7.5 & 7.1 & 7.6 & 7.0 & 7.2 \\
\hline \multicolumn{15}{|c|}{$m g / l$} \\
\hline TDS & 57 & 161 & 85 & \begin{tabular}{|l}
5388 \\
\end{tabular} & 90 & 270 & 84 & 500 & 43 & 76 & 40 & 90 & 69 & 99 \\
\hline $\mathrm{HCO}_{3}^{-}$ & 22 & 72 & 1.2 & 18 & 19 & 43 & 21 & 47 & 19 & 25 & 20 & 23 & 18 & 23 \\
\hline $\mathrm{Cl}^{-}$ & 3.2 & 4.3 & 2.7 & 11 & 3.8 & 13 & 6.1 & 17 & - & - & - & - & - & - \\
\hline $\mathrm{SO}_{4}{ }^{2-}$ & 17 & 77 & 55 & 4226 & 32 & 168 & 26 & 322 & 5.9 & 37 & 11 & 46 & 33 & 56 \\
\hline $\mathrm{Ca}^{2+}$ & 8.2 & 25 & 13 & 388 & 3.4 & 40 & 9.1 & 64 & 4.6 & 9.4 & 4 & 13 & 8.0 & 15 \\
\hline $\mathrm{Mg}^{2+}$ & 1.1 & 9.2 & 5.8 & 755 & 0.2 & 20 & 4.8 & 39 & 3.0 & 5.0 & 2.6 & 7.8 & 5.0 & 10 \\
\hline $\mathrm{Na}^{+}$ & 1.7 & 2.2 & 2.1 & 16 & 2.9 & 28 & 1.0 & 62 & 0.5 & \begin{tabular}{|l|}
0.8 \\
\end{tabular} & \begin{tabular}{|l|}
0.4 \\
\end{tabular} & 1.0 & - & - \\
\hline $\mathbf{K}^{+}$ & 0.4 & 1.3 & 0.3 & 2.9 & 5.2 & 15 & 4.7 & 44 & 2.5 & 2.5 & 1.0 & 2.6 & - & - \\
\hline \multicolumn{15}{|c|}{$\mu g / l$} \\
\hline $\mathbf{C u}$ & 3.3 & 11 & 250 & \begin{tabular}{|l|l|}
18759 \\
\end{tabular} & 3.0 & 70 & 7.3 & 72 & 4.9 & 84 & 5.0 & 55 & 3.4 & 11 \\
\hline Mo & 0.1 & 0.3 & 0.3 & 8.9 & 0.6 & 118 & 4.0 & 22 & 2.1 & 2.7 & 1.5 & 1.9 & 1.3 & 2.2 \\
\hline $\mathbf{Z n}$ & 2.5 & 13 & 40 & 3998 & 2.3 & 283 & 2.1 & 6.0 & 3.0 & 5.3 & 2.5 & 8.3 & 2.1 & 7.3 \\
\hline $\mathbf{P b}$ & 0.1 & 0.8 & 0.03 & 20 & 0.3 & 5.0 & 0.3 & 1.2 & 0.5 & 0.9 & 0.3 & 0.3 & 0.1 & 1.2 \\
\hline As & 0.2 & 0.9 & 0.4 & 3.8 & 0.1 & 5.1 & 0.6 & 51 & 1.3 & 19 & 3.4 & 6.1 & 4.8 & 8.4 \\
\hline Cd & 0.01 & 0.03 & 0.3 & 12 & 0.04 & 1.7 & 0.05 & 0.3 & 0.03 & \begin{tabular}{|l|}
0.1 \\
\end{tabular} & 0.02 & 0.1 & 0.05 & 0.1 \\
\hline $\mathbf{F e}$ & 9.0 & 20 & 131 & 8935 & 1.7 & 31 & 1.8 & 66 & 1.8 & 25 & 1.5 & 11 & \begin{tabular}{|l|}
0.7 \\
\end{tabular} & 3.2 \\
\hline Mn & 1.5 & 9.0 & 269 & 55965 & 30 & 1900 & 22 & 300 & 14 & 71 & 16 & 65 & 15 & 47 \\
\hline
\end{tabular}

Except high-pyrite rocks at the initial stage of "water-rock" interaction, both in static and kinetic modes, $\mathrm{pH}$ varies from 7.0 to 8.1 ; total dissolved solids (TDS) is $0.08-0.50 \mathrm{~g} / \mathrm{l}$. The main anion is sulfate, its share is from 59 to $93 \%$ (accordingly, the proportion of bicarbonate-ion does not exceed $40 \%$ ). Calcium and sodium are predominant cations. In terms of metal content, drainage water at this stage are mainly low-metal (Fig. 1A). Thus, experimental data indicate the absence of visible signs of acid mine drainage. Leachates for high-pyrite rocks are characterized by low $\mathrm{pH}$ (3.3-4.7), TDS of $0.4-0.9 \mathrm{~g} / \mathrm{l}$, content of sulfate in the solution at the range of $98-100 \%$. 

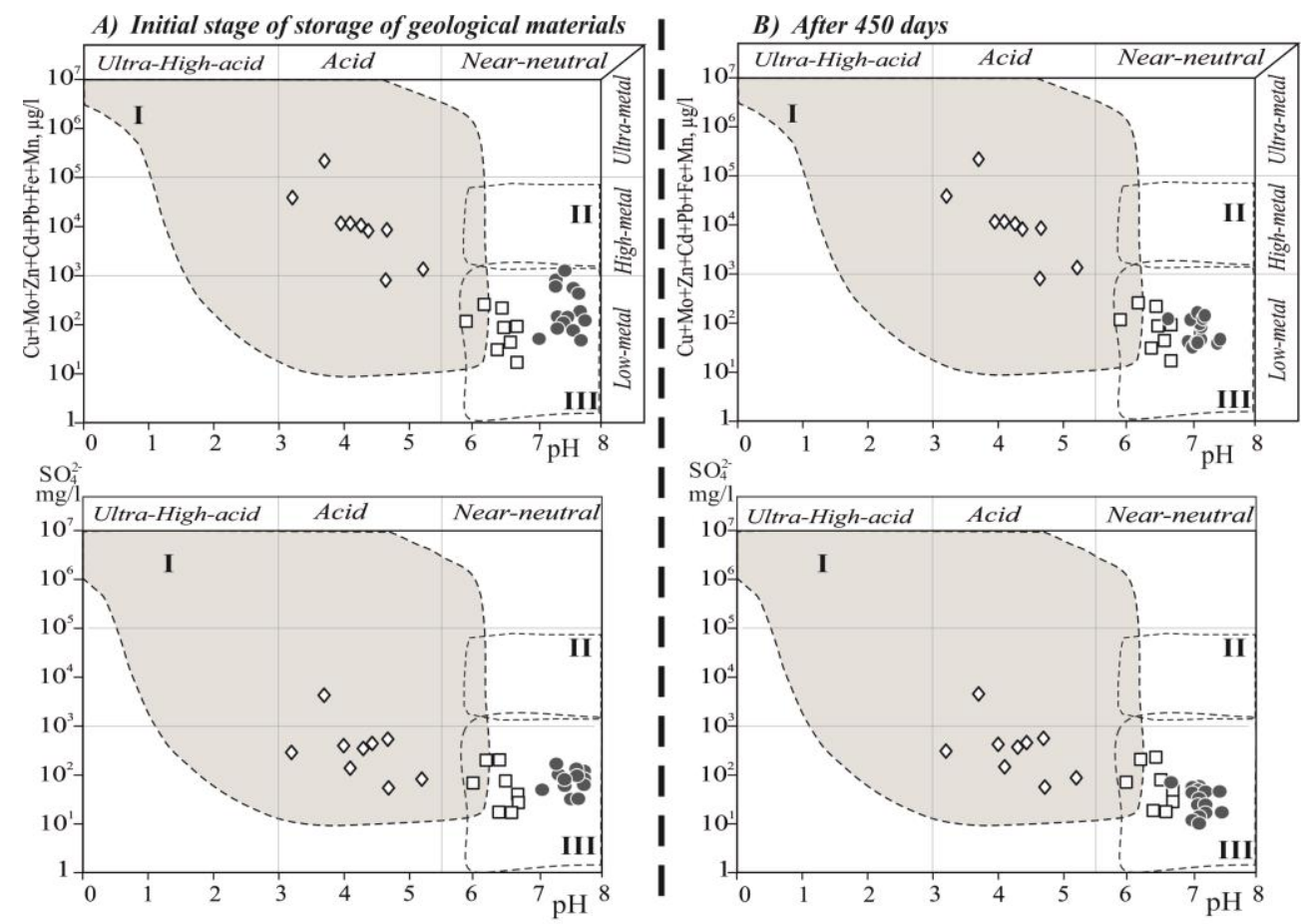

I-acid drainage, II-high-salinity water, III-neutral drainage [2]

potential drainage water: $\square$ leachates for geological sulphide-bearing materials surface water [4,5]: $\square$ background plots; $\square$ draining porphyry Cu system

Fig.1 Ficklin plot displaying sum of dissolved metals and sulfate as a function of $\mathrm{pH}$ at the initial stage and in the long-term of geological materials storage.

Laboratory studies of alteration of potential drainage water composition show that $\mathrm{pH}$ value remains unchanged for the entire period of the experiment and persists on the nearneutral range (Fig. 2), but slightly higher than in surface water (Fig.1B). The main phase of leaching is observed at first 90-days period (Fig. 2), then contents of basic ions remains at a constant level up to present. Due to dissolution and removal of sulphate at the initial stage of weathering (Table 1) bicarbonate and calcium are the main ions in leachates.

The contents of trace metal in weekly filtrates also decrease; from 10 weeks of the experiment, in general, they are comparable with ones to surface water in the background plots (Fig. 1B).
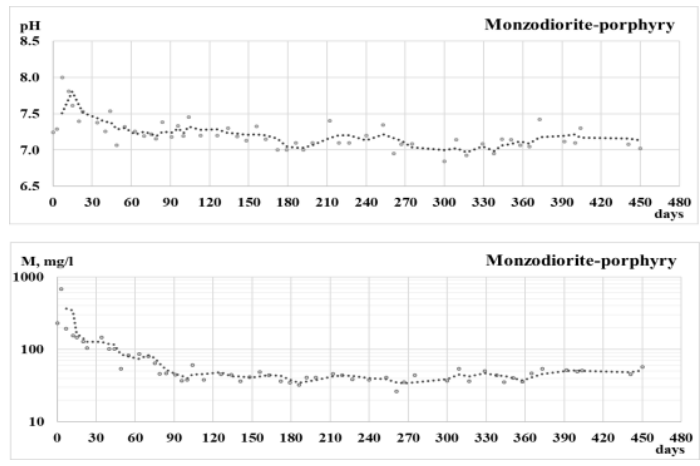

Fig.2 Plot of kinetic humidity cell test results. 


\section{Conclusion}

An experimental study has been conducted to simulate the weathering of rocks of the Nakhodka porphyry copper ore prospect and to estimate potential drainage water composition as well at the initial stage of storage of sulphide-bearing geological materials as over the long-term.

At the initial stage, drainage water composition is similar to one of surface watercourses but can differ by higher levels of $\mathrm{pH}$ and trace metals (except high-pyrite rocks). Long-term interaction of rocks and atmospheric precipitation also doesn't lead to formation of acid high-metal drainage water: $\mathrm{pH}$ value of weekly filtrates remains in the near-neutral range, the contents of major ions and trace metals reduce after 10 weeks of the experiment and corresponds to background level in natural surface water.

It has been established that the buffer capacity of geological materials ensures the conservation of near-neutral $\mathrm{pH}$ values, which prevents the processes of metal leaching for a long time. In the same time, storage the high pyrite rocks in dumps can lead to the formation of acid high-metal drainage water already in a short-term.

\section{References}

1. S.S. Smirnov, The oxidation zone of sulfide deposits (PAS USSR, Moscow, 1951)

2. Global Acid Rock Drainage (GARD) Guide. Available: http://www.gardguide.com/images/5/5f/TheGlobalAcidRockDrainageGuide.pdf

3. Y.N. Nikolaev, I.A Baksheev, V.Y Prokofiev et al., Geol. Ore Deposits, 58, 284 (2016)

4. T.N. Lubkova, D.A. Yablonskaya, T.V. Shestakova, V.V. Pukhov, Wat.: Chem. and Ecol., 12, 29 (2013)

5. T.N. Lubkova, D.A. Yablonskaya, T.V. Shestakova, O.A.Lipatnikova, Wat.-Rock Int.: Geol. Ev., 481 (2015)

6. D.A. Yablonskaya, T.N. Lubkova, T.V. Shestakova et al., SGEM, 52, 63 (2017) 